\title{
Research on the Construction Model of Urban Youth Innovation and Entrepreneur Club
}

\author{
Jiping Pan \\ Panzhihua University, Panzhihua, Sichuan, 617000
}

Keywords: construction model; youth innovation; entrepreneur club; control charts, process capability

\begin{abstract}
Urban youth innovation and entrepreneurship club is an important platform and carrier for the school's innovation and entrepreneurship work. Its operation management is of great significance to the benign development of the dual-creation work. This paper focuses on the actual situation of colleges and universities, thinks about the orientation of innovation and entrepreneurship clubs, the establishment of institutions, the determination of functions, etc., and puts forward some viewpoints. It is hoped that the development of innovation and entrepreneurship in some higher vocational colleges, the creation of atmosphere and the incubation of projects will have an active effect.
\end{abstract}

\section{Introduction}

In the report of the 19th National Congress of the Communist Party of China, General Secretary $\mathrm{Xi}$ Jinping pointed out that "innovation is the first driving force for development and the strategic support for building a modern economic system." "Public entrepreneurship, innovation" as a major strategic deployment of the country, then innovation and entrepreneurship education is an important direction of college education reform, schools of different professional categories have different positioning of innovation and entrepreneurship, which leads to some schools for innovation The construction investment and construction content of the entrepreneurial club cannot meet the relevant requirements. This article first analyzes the current situation of club construction and puts forward some thoughts.

Premier Li Keqiang emphasized that college students are the new force to implement the innovation-driven development strategy and promote mass entrepreneurship and innovation. It is the intellectual intelligence support for building an innovative country. On the one hand, college students, as a special group, have received higher education, are based on professional knowledge and technology, have new ideas, represent the most advanced popular culture, and are an important force to promote national development. However, college students have not fully entered the society, their social experience is not enough, and their experience is still shallow. College students' entrepreneurship is different from other social groups. It needs more material and spiritual support from the state, society, universities and families. On the other hand, as an important base for talent cultivation and scientific and technological innovation, colleges and universities shoulder the heavy responsibility of cultivating high-quality talents that are suitable for economic and social development. The implementation of the innovation-driven development strategy by the state will inevitably require the positive response of colleges and universities, and provide a support platform for college students' innovation and entrepreneurship education and college students' innovation and entrepreneurship practices. •

In recent years, urban youth innovation and entrepreneurship clubs, college students' science and technology parks or incubators have mushroomed. According to statistics, as of 2015, the number of undergraduate science and technology entrepreneurship parks reached more than 200, and the total area of entrepreneurial parks was 10 million square meters. 8,000 entrepreneurial projects were introduced, 5,000 graduated enterprises were launched, and 100,000 entrepreneurial talents were trained. And the city youth innovation and entrepreneurship clubs, college students' science and technology entrepreneurship parks or incubators rely on the establishment of university resources, 
to a certain extent can promote their long-term development, and ultimately provide reliable support for the national innovation strategy. However, urban youth innovation and entrepreneurship clubs, college students' science and technology parks or incubators are still new things, and the establishment time is short. Colleges and universities lack experience in how to scientifically manage such institutions. The system construction in the club or the hatchery is relatively lagging behind, and there is a lack of a sound and systematic management and operation system, which will become an important factor restricting the efficiency, effectiveness and sustainable development of the club.

\section{Management Status of Urban Youth Innovation and Entrepreneurship Club}

Human management is the core of management, and the other three main management objects (financial, material, and information) of the modern management system are managed and operated by people. Therefore, an important task in the construction of the management system for urban youth innovation and entrepreneurship clubs is to establish an organization of professional clubs, establish a clear division of responsibilities, and equip professional management personnel.

The department of the Urban Youth Innovation and Entrepreneurship Club is not uniform, and there is no organization of a professional club and a clear division of responsibilities. Take some colleges and universities in Guangxi and Liaoning as an example. The urban youth innovation and entrepreneurship club is entrusted to operate by the employment department of the school. In addition, some colleges and universities are responsible for the school youth league committee or the academic affairs department, and some of the affairs involve the school science and technology department. In some universities, innovation and entrepreneurship are managed separately. Taking Chengdu Medical College as an example, the innovation-related work is the responsibility of the Academic Affairs Office, and the entrepreneurial activities are the responsibility of the Youth League Committee or the Employment Guidance Center. With this management model, if the departments have not collaborated before, it is easy to cause inter-departmental push and reduce work efficiency. According to the research data of more than 20 colleges and universities in Hangzhou, $36.21 \%$ of the recommended schools should set up a special urban youth innovation and entrepreneurship club management department. Although some universities have established specialized business park management departments, they are basically affiliated with The actual work of a school or college is based on the college and students, and lacks independent institutional management and a sound management system. In the urban youth innovation and entrepreneurship club, the single administrative management model has been adopted, which has made it impossible for the club to establish a professional organization, and it is difficult to establish a clear division of responsibilities. The city youth innovation and entrepreneurship club mostly adopts the school-led guidance and is handed over to students for self-management and practical operation. Take most universities in Beijing as an example. Due to the serious shortage of managers, only students are hired to manage the daily affairs of the club. Take the Tongji University Student Innovation Club Management Model as an example. The entire management organization is composed of students, and various activities are planned by students. In the case of a serious lack of full-time managerial staff, the student management model is used in the daily operation management of the club, which can improve the efficiency of the club to some extent. However, the Urban Youth Innovation and Entrepreneurship Club is different from other student organizations. Its functional orientation is that the institutions that provide innovative and entrepreneurial services and support for college students should be of the same nature as other functional departments of the school. Other similar entrepreneurial parks or incubation bases in the society are also managed and operated by full-time managers. And, in addition to the day-to-day management of the club, the core of club management is to ensure the normal operation of the entry project, which involves the operation of hardware facilities, business project screening, policy and information consultation, risk control, etc. Personnel to guide and monitor. Taking a study on the management of venture capital funds as an example, the evaluation of some college entrance projects is led by the school's entrepreneurial management function department, which is responsible for finance, academics, and the Communist 
Youth League. The staff of the school's administrative function department did not practice entrepreneurial experience, so that they would review the admission project as if it were on paper. This approach completely ignores the professionalism of project selection. Due to the lack of participation of relevant professionals, it is impossible to conduct an effective risk assessment of the project's development prospects and profitability, and increase the risk of project entry. Lack of full-time managers, lack of professional entrepreneurial mentors and project reviewers will be an important factor constraining club development. The mode of hiring students to manage can only temporarily cope with the lack of professional management personnel, and does not apply to the long-term development strategy of the city youth innovation and entrepreneurship club.

\section{Thoughts on the Construction of Youth Innovation and Entrepreneur Club in $\mathbf{3}$ Cities}

Identify the positioning of innovative and entrepreneurial clubs. In accordance with national policies and the functions of the club itself, higher vocational colleges and universities should focus on the creation of a school's innovation and entrepreneurial atmosphere, and actively carry out entrepreneurial salons, excellent entrepreneurial project sharing, policy transfer, etc., while expanding The scope of activities, not just a small number of entrepreneurial students. This not only meets the actual needs of the dual-creation work of higher vocational colleges, but also is more conducive to the development of clubs in higher vocational colleges. Establish an effective organization. First of all, it should be clear that the Urban Youth Innovation and Entrepreneurship Club is a student organization, and the level is the same as that of the school-level student union. The specific business management is managed by the School Innovation and Entrepreneurship Leading Group Office. The funds are listed separately and a full-time teacher position is established. The club itself establishes a board of directors and the students are responsible for the operation. In this way, under the leadership of the school organization level, working under the specific guidance of full-time teachers is more conducive to the club to fully utilize the resources of the school and the external contacts to effectively improve work efficiency. Of course, the purchase and purchase of third-party services can also be used to complete the management and operation of the club, as permitted by existing policies. Enrich the source of the project and integrate the tutor library. The entry of the club project is not limited to the participation of students. It can actively guide the teachers to bring the students to the club, which is also in line with the current requirements of teachers and students. Actively carry out the university students' innovation and entrepreneurship training program, carry out double-creation work from the lower grades, strengthen inter-school exchanges, and carry out project interaction activities with school-enterprise cooperation enterprises and incubation platforms to achieve breakthroughs in project sources. Liberal arts schools can adjust the project studio to an activity room, adding pure innovation and entrepreneurship to the cultivation of creativity. Strengthen the construction of informatization, make full use of the existing communication software, realize the remote guidance of the tutor, and establish a classification tutor group to integrate various types of tutors in the region.

Improve the system and actively create an atmosphere of innovation and entrepreneurship. Establish a complete management system from the entrance and exit of the club to the use of funds, project management, and activities. And make full use of all kinds of new media to timely and effectively deliver information on various innovation and entrepreneurship policies and activities. Establish cooperative relationships with external institutions to provide effective services for students from the financial, business and other aspects, so that students can fully understand the functions of the club and get benefits, thus enhancing the enthusiasm of student activities. Strengthen publicity work and let more students participate in the Innovation and Entrepreneurship Club. The College Youth Innovation and Entrepreneurship Club establishes publicity positions such as websites, WeChat platforms, and QQ groups, and vigorously promotes the advanced models of college students' innovation and entrepreneurship and the dynamics of club work through various channels such as the Internet, broadcasting, publicity columns, and school newspapers. Actively cultivate and explore the typical innovation and entrepreneurship of college students, and select outstanding entrepreneurial teams and entrepreneurial stars every year. Expand publicity through 
various selections and events to allow more students to participate in innovation and entrepreneurship activities. Actively carry out innovation and entrepreneurial activities. It mainly includes three categories: The first category is all kinds of innovation and entrepreneurship competitions, such as the school's scientific and technological works competition, innovation and entrepreneurship knowledge competition, entrepreneurship plan competition, provincial and national "challenge cup" national college students' extracurricular academic and scientific works competition, the whole country. College students' business plan competitions, etc. The second category is simulated entrepreneurial activities, including purely simulated competitions, such as corporate sandbox competitions, as well as social practice activities carried out by simulated enterprises and social innovation practice activities of college students during the summer and winter. The third category is a legal entity such as a registered studio or a company, and a well-established team adopts this model. At present, the state, provinces and municipalities attach great importance to the construction of urban youth innovation and entrepreneurship clubs, and implement demonstration club construction projects to provide financial support. Schools should make full use of this opportunity to establish a city youth innovation and entrepreneurship club in line with the professional settings and local regional economic reality to promote the sustainable development of school innovation and entrepreneurship.

\section{Conclusion}

The construction of the management system of urban youth innovation and entrepreneurship clubs lags behind, mainly due to the lack of professional club organization and clear division of responsibilities, lack of full-time management personnel and professional entrepreneurial tutors, lack of systematic management system in daily operation, and lack of integration. Entry project management system. On the one hand, speed up the construction of a systematic urban youth innovation and entrepreneurship club operation management system, institutionalize all management affairs, and constrain and guide the specific operation of the club through the system, which will enhance the operational efficiency and effectiveness of the urban youth innovation and entrepreneurship club. To promote the sustainable development of the club. On the other hand, the construction of the operation management system of the city youth innovation and entrepreneurship club is still in the initial stage, and it is necessary to continuously sum up experience and constantly improve in the practice process of the club management operation.

\section{References}

[1] Tan Xiaoyan. An Empirical Study of College Students' Pioneering Parks in Higher Vocational Colleges_A Case Study of Guangxi International Business Vocational and Technical College [J]. Higher Education Forum, 2012(8): 131-133.

[2] Liu Zhu. Research on the Construction of University Graduates' Entrepreneurial Incubation Base in Liaoning Province [J]. Liaoning Education Research, 2006(6): 79-82.

[3] Li Wei, Lin Yimin. Analysis of the Status Quo of College Pioneer Park Construction and Its Development Countermeasures [J]. China Science and Technology Information, 2012(22): 147-158.

[4] Ren Jia, Wang Jie, Liang Yong. Analysis of the construction of innovative practice bases in Beijing universities [J]. Experimental Technology and Management, 2014: 222-224.

[5] Wang Dong. Analysis on the Management of College Students' Venture Capital Funds [J]. Education Accounting Research, 2015(2): 88-91. 